\title{
Scenographer Antonín Heythum and His Work in the US: The Case of King Lear
}

\author{
Vlasta Koubská
}

\begin{abstract}
The article focuses on the stage designs of Antonín Heythum. Heythum's work during the interwar period is relatively well known and has been (somewhat incorrectly) aligned with Constructivist scenography. There are a number of materials for his designs for the Liberated Theatre (Osvobozené divadlo) (e.g. Circus Dandin, Když ženy něco slaví [When Women Celebrate]) and other Czech theatres (Olomouc, Ostrava, and others). We, however, have only scarce information about his work in the US, where he lived after 1939. The article discusses Heythum's war and post-war life and work paying special attention to the production of King Lear, an extraordinary stage experiment directed by Erwin Piscator in New York. The article also examines Heythum's pedagogical activities in the United States.
\end{abstract}

\section{Keywords}

Antonín Heythum, scenography, King Lear, Erwin Piscator, New School of Social Research, American Design 


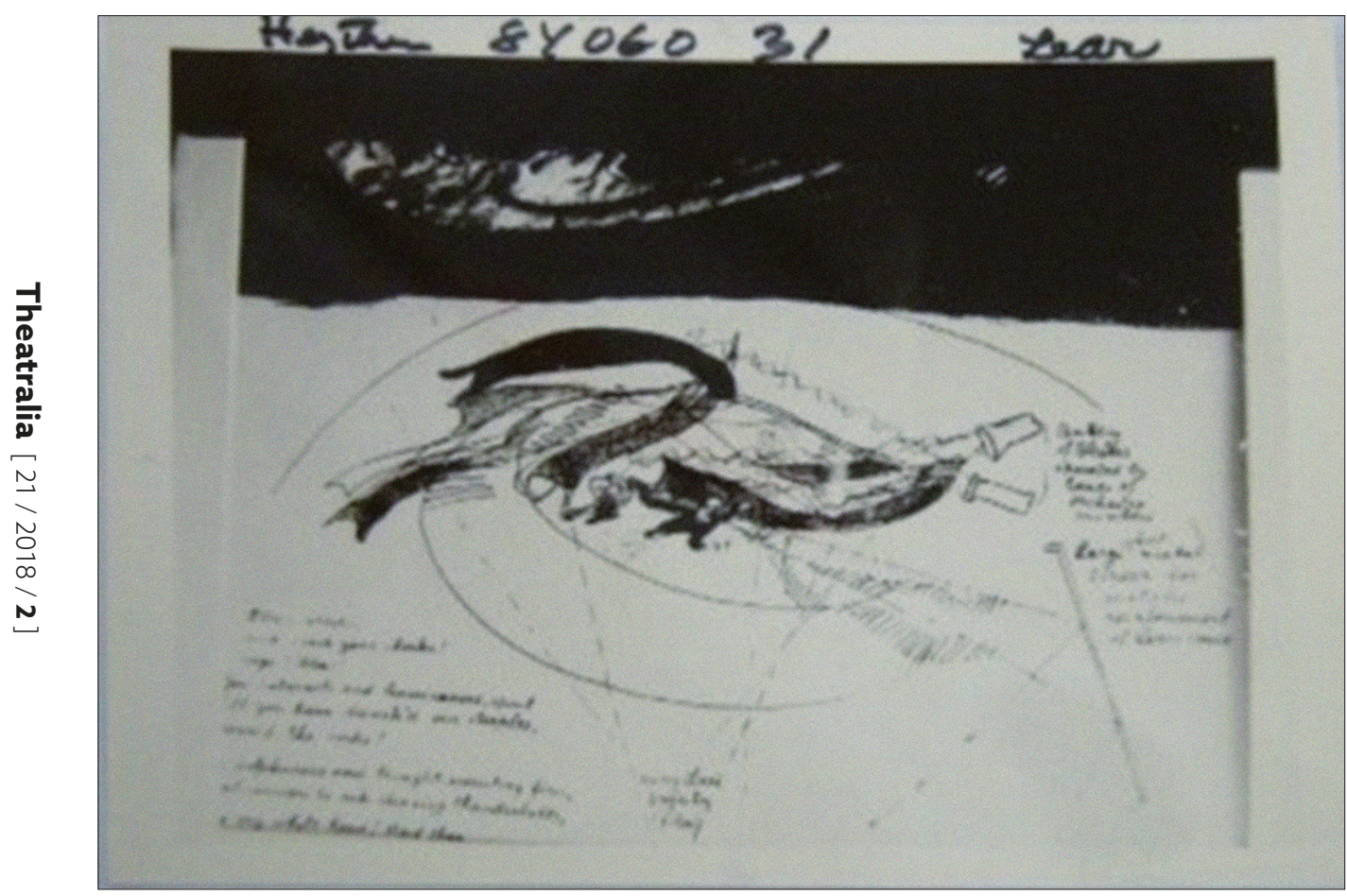

Fig. 1: Sketch A. Heythum. King Lear. Thompson Library. Nena Couch. TRI.JAR.1.2.13 HEYTHUM 84060.31 Heythum - Lear.

A search for more details of the creative work of Antonín Heythum (1901-1954) during his life in the US started with a single tiny photograph found in the Jarka M. Burian archive in the Special Collections of the Thompson Library, Ohio State University. This was discovered while I was working with the scenographic and archival collection created by Professor Burian and used by him for his lectures and publications on Czech theatre. ${ }^{1}$ It has been known for a long time that Antonín Heythum, during his stay in the US, lectured at a number of universities and made several scenic designs for theatre productions; however, the details haven't as yet been researched. The minute photograph has contributed greatly to the knowledge of the US work of this outstanding scenographer. This essay uncovers the details and circumstances of his scenography for an experimental production of King Lear, directed by Erwin Piscator in New York City in December 1940.

Antonín Heythum's work belongs to the best specimens of Czechoslovak scenography between the two World Wars, thanks to its progressive nature, its engineering ingenuity, its refined work with lights, its original usage of the traditional system of wings and decorations and its unprecedented tendency towards abstraction. Heythum's work is relatively well known and has been aligned with Soviet Constructivist scenography. However, such a 'short connection' is somewhat inaccurate.

1 I would like to thank Prof. Nena Couch and the Jerome Lawrence and Robert E. Lee Theatre Research Institute of Thompson Library, The Ohio State University Libraries Special Collections. 
Together with the leading Avant-garde director Jiří Frejka (1904-1952), Heythum tried to articulate the scenographer's position within the theatrical production, in such essays as 'Rekvizita na jevišti a jevištní asociativní faktor' [The Onstage Prop and the Onstage Associative Factor] (FREJKA 1925a) or 'O konstruktivní scénu u nás' [Towards Our Constructivist Stage] (FREJKA 1925b). In an essay called 'Spolupráce režiséra a architekta na divadle' [The Director's and Architect's Collaboration in the Theatre] (FREJKA and HEYTHUM 1925), Heythum and Frejka formulated the role of scenography: 'Scénografie je definována jako divadelní architektura. Scénograf (konstruktér scény) je architektem jevištních emocí. [Scenography is defined as theatrical architecture. The scenographer (engineer of the stage) is the architect of scenic emotions.]' (FREJKA and HEYTHUM 1925).

It is mainly the formal similarities, such as the visible construction of the scenic build, that may remind us of Russian Constructivist scenography, but the marked affinity to Futurism, machinism and mechanical movements, the relations to Cubo-Futurist forms expressing the movement, restlessness and pulse of modern civilisation, which perceives the world as a machine with humans as its indelible parts, that is totally different in Heythum. The typical Constructivist scenographic idea of such creators as Lyubov Popova (her scenography for Meyerhold's 1922 production of Fernand Crommelynck's The Magnanimous Cuckold) or Alexander Vesnin (his design for Tairov's 1923 production of The Man Who Was Thursday after G. K. Chesterton), portraying humans as slaves to the machinery of the world, is completely absent from Heythum's work. However, Heythum could be seen as a Constructivist, within Karel Teige's concept:

Konstruktivistická estetika neuznává apriorní princip tvaru; tvar vyrůstá z účelu, z materiálu a konstrukce, je resultátem splněné funkce. Na místo tradičních ideálů umělecké krásy klade konstruktivistická estetika jako požadavek maximální funkčnost, tedy princip věcné dokonalosti... kontruktivismus ví, že dokonale konstruovaná a maximálně fungující forma je krásná...

[Constructivist aesthetics refutes an a priori principle of form; form derives from purpose, from material and construction; it is an outcome of a fulfilled function. In place of the traditional ideals of artistic beauty, Constructivist aesthetics places an emphasis on the requirement of maximal functionality, i.e. the principle of factual perfection... Constructivism knows that a perfectly constructed and maximally functional form is beautiful...] (TEIGE 1927: 7-24)

It is in Teige's definition of Constructivism as a functionalist aesthetic that Heythum can be associated with the school.

The variation and colourfulness of shapes in Heythum's scenic objects as opposed to Russian Constructivists' semantic objectlessness also suggested real objects and spaces. The poetics of his stage designs took inspiration in the plural meanings of basic shapes that evoke various contents and associations. Heythum tended to activate the vertical dimension of the performers' action with a purpose to stirring the youthful energy of the stage space - as in the childlike joy of discovering the world, playing with everyday objects, which imagination enriches with unexpected and manifold meanings. 
Heythum's early scenographic work was initially associated with the Liberated Theatre (Osvobozené divadlo) and its experimental phase; in this period, Heythum collaborated with Frejka. Later Heythum made designs for the theatre in Olomouc, achieving remarkable effects through progressive lighting of abstracted scenic objects. The interwar period of Heythum's scenic work culminated in his designs for the National Theatre in Prague, such as Karel Dostal's production of The Merchant of Venice (1931), which is among the most progressive works of the Czech theatre Avant-garde.

It is of importance to note that Heythum was a graduate of the Czech Technical University (České vysoké učeni technickê) in the following disciplines: architecture, civil engineering and construction, as well as ship engineering. The latter discipline must have had an impact on his scenic vision and his engineering skills contributed to the variety of his scenic work. Heythum's wooden constructions are exceptional features of Czech scenography, both from a spatial and a visual point of view. Their static and solid qualities had to be sufficient to accommodate actors and their physical activities. This was particularly at stake in such productions as When Women Celebrate (Kdyžženy něco slavi); Cirkus Dandin; The Mute Canary (Němý kanár, 1926) at the Liberated Theatre; Desire Under the Elms (Farma pod jilmy, 1925) at the National Theatre in Prague; or in Doña Sancha (Doña Sanča, 1927) in Olomouc. Between 1921 and 1937, Heythum created about almost a hundred stage designs in 14 different theatres; however, these are outside of the focus of this essay.

Architect Kamil Roškot invited Antonín Heythum to collaborate with him on the interior designs for the Czechoslovak pavillion of the World Exhibition in New York City in 1938-1939. This invitation came on the basis of Heythum's previously exceptionally successful exhibition designs, such as the exposition of glass at the world exhibition in Paris (1937), a pavillion at the world exhibition in the Brussels (1935), or the exhibition of the Institute of Glass Research in Prague (1934). It was during the work on the exhibition in 1938 that Heythum and his wife Charlotta decided not to return to Europe, ridden by Nazism. Even when World War II was over, they decided to remain in the United States for good. The immediate concrete reasons for not returning to Europe in 1938 are unknown but there were probably two significant impulses. One was the fact that they belonged to the Avant-garde (i.e. Leftist) movement; in 1936, many Avantgarde visual artefacts were listed by the Nazi regime in Germany as 'Entartete Kunst' (perverted art) and their creators were banned from continuing their artistic work. The second impulse probably was that Heythum had been active with the Scout Movement since 1919, when he made the Scouts' solemn vow in the presence of US Major L. J. Riout in Moravská Ostrava; in 1925, probably as part of his involvement with the movement, Heythum refurbished the grave of the poet and Scout Jiří Wolker in Prostějov. ${ }^{2}$ These two reasons would be sufficient for the Heythums to find their future in the Protectorate of Bohemia and Moravia perilous.

On arrival in the US, the Heythums started teaching at the New School for Social Research in New York. Charlotta taught graphics and Antonín architecture. The faculty

2 Further information available at: http://www.pametnaroda.cz/story/cermak-lumir-1923-1964. 
was truly international: apart from a few Czechoslovaks like the Heythums, there were German, Austrian, Russian, French, Belgian, Italian, Hungarian and Polish teachers. The archival listings of The New School history give other Czechoslovaks teaching history (Erich Kahler), law (Hans Kelsen), biochemistry (Julius Pless, Eugene Sagi) or psychology (Max Wertheimer). ${ }^{3}$ The same list also gives the name of the renowned German theatre director Erwin Piscator, as a scholar of 'theater arts'. These European artists and intellectuals, with the Heythums among them, got to the US thanks to the generous Refugee Scholar Program, financially supported by the Rockefeller Foundation. The New School for Social Research hosted 183 scholars during World War II, many more than other US institutions. It was the Rockefeller Foundation that helped rescue a significant proportion of all 303 scholars.

The catalogue entitled 'CURRICULUM The New School for Social Research, Spring 1941' provide the exact titles of lectures and seminars delivered by individual scholars. ${ }^{4}$ Programme of the Field of Study 97 The Art of Display gives Antonín Heythum as the teacher, 'assisted by Charlotta Heythum' (61). This catalogue was published towards the end of 1940; Heythum's plan of lectures for the spring term from February 1941 was as follows: ${ }^{5}$

A. LECTURE DEMONSTRATION SEMINAR. 15 weeks. Wednesdays, 8:20-10 P.M. $\$ 12.50$. Beginning February 5. For beginners and advanced students of design and architecture, photographers, teachers, display designers and artists in other fields. The lectures, illustrated by slides, deal with the elements of design for private and commercial interiors as well as for show window and exhibition display. The practical, emotional and educational value of good display design is analyzed in its relation to the psychological and the physical characteristics of the visitor-buyeronlooker.

Guest lecturers include John McAndrew, curator of architecture, Museum of Modern Art, on theme exhibitions at the Museum; Ernst Kris, professor of psychology at the New School, on the visitorbuyer-onlooker.

Students are encouraged to present individual problems in the fields analyzed, in so far as they are of interest and benefit to the class, thus helping to bring out the students' special inclinations and abilities.

B. EXPERIMENTAL LABORATORY. 15 weeks. Wednesdays, 6:10-7:50 P.M. \$20.

Beginning February 5. Students are given opportunity to elaborate various tasks which may be of especial interest to them, including sketches, plans, models, montage, diagrams, formulation

3 The list of exiled scholars at the New School is available at: http://thenewschoolhistory.org/?page_id=280

4 Curriculum The New School for Social Research, Spring 1941. The New School Archive Digital Collection [online]. New York. Available at: http://digitalarchives.library.newschool.edu/index.php/Detail/objects/ NS050101_ns1941sp.

5 New School (New York, N.Y.). Curriculum The New School for Social Research, Spring 1941, circa 1940. New School course catalogs; Public Engagement course catalogs; General course catalogs. New School Archives and Special Collections Digital Archive [online]. [accessed on 23 Mar 2017], pages 6, 61-62. Available online at: http://digitalarchives.library.newschool.edu/index.php/Detail/objects/NS050101_ns1941sp. 
of program, etc. At the conclusion of the course the attempt will be made to correlate the work of the class in a small model theme exhibition.

Aspects of the work of both courses include:

I Interdependence of architecture and interior design. General layout, plan. Scale, color, light, texture values. The art of composition. Creation of atmosphere. Theatrical effects applied to display design. Surprise elements. Harmony and disharmony as means of effect.

II Use of sound, movement, smell, technical devices. Character and display value of art objects, goods, facts. Means of presentation. Labeling, lettering, contents, formulation and style of texts and legends.

III The sense and value of exhibitions. The idea of themes. Specific exhibition materials. The important adjuncts to modern display design: photography and motion picture, their use as an integral part in display composition in the form of montage.

Heythum's lectures on 'the art of display' were based not only on his rich experience as an architect and designer of renowned exhibition concepts but also on his practice as a progressive scenographer. The catalogue explicitly cites 'theatrical effects applied to display design', including also 'scale, color, light, texture values [; ... the] creation of atmosphere [and] surprise elements [; or] harmony and disharmony as means of effect'. All these had been propped up by his past practice; in the lecture outlines, these aspects blended in a remarkable way and formed an entirely new perspective of the subject matter. His use of new technologies, sounds, 'photography and motion picture' was cutting-edge.

Charlotta, who assisted him in these lectures, had received an excellent education at the École d'Humanité in Switzerland (formerly Odenwaldschule in Heppenheim in Germany). Early in the century the school belonged to the most progressive educational institutions of a new type, informed by reformed theories of modern learning. Its founders, Edith and Paul Geheeb were inspired by the classical Greek poet Pindar's line 'be

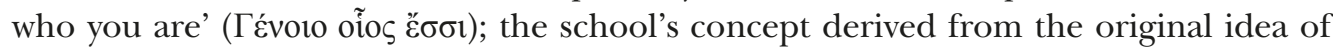
'work schools' and the faculty comprised international teachers (from the USA and the United Kingdom). Odenwaldschule was an open community inhabited by students of different ages, working together and inspiring one another. Children and adolescents were to obtain high-quality individual training on three basic principles: intellectual, practical, and musical/artistic. ${ }^{6}$ In 1934, the Geheebs, alongside two dozen of their students and teachers, moved the school to Switzerland, establishing l'École d'Humanité. Charlotta (born 6 January 1906; died 23 November 1997) was four years Antonín's junior and had collaborated with him earlier as a visual artist. In her biography, ${ }^{7}$ she mentions an active involvement in the technical and preliminary works for the Czechoslovak

6 The school continues to this day. Available online at: https://www.ecole.ch/en/philosophy-andmission-statement

7 New School (New York, N.Y.). Curriculum The New School for Social Research, Spring 1941, circa 1940. New School course catalogs; Public Engagement course catalogs; General course catalogs. New School Archives and Special Collections Digital Archive [online] [accessed on 23 Mar 2017], page 69. Available online at: http:// digitalarchives.library.newschool.edu/index.php/Detail/objects/NS050101_ns1941sp. 


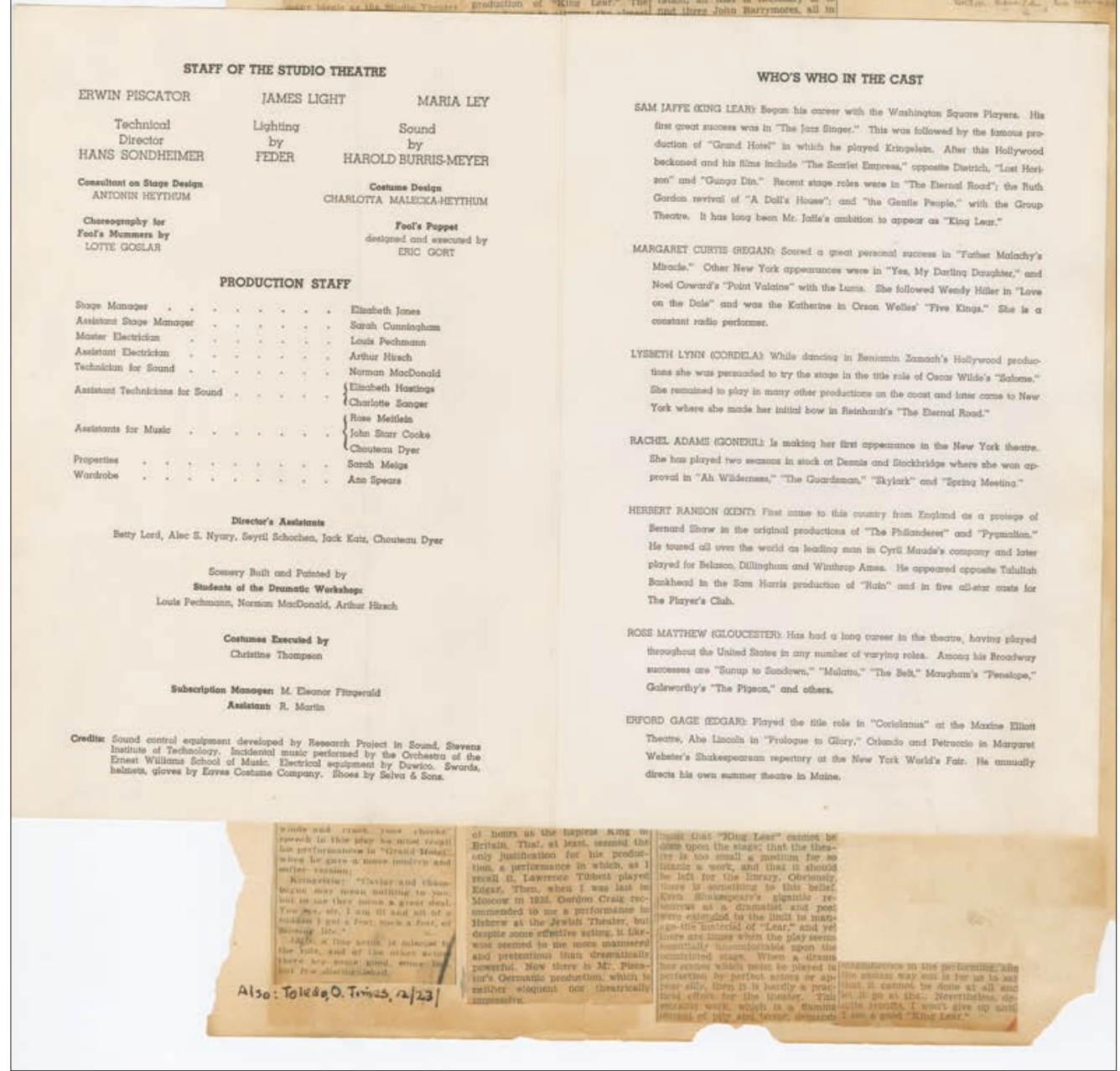

\section{THE THEATER}

MAKES REVIVAL OF 'KING LEAR'

ns youk kunos

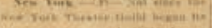

1 Satiafuetory "Lear" It Sail in the Fature

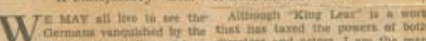

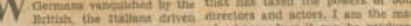

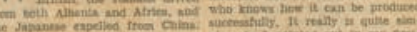

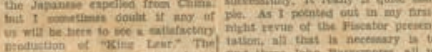

Honk Bam
Creich ales in

Raleigh,ike. Newe-

Observey, $2 / 20 /$ we.

A, bury lack, in

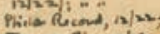

$T a-p a, F L, N / 2$,

New Deifor thes, Tinis

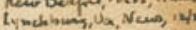

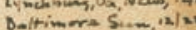

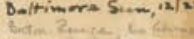

Fig. 1: The programme for the premiere of the King Lear production, 1942.

(New School Publicity Office records. The New School Archives and Special Collection, The New School, New York, NY). 


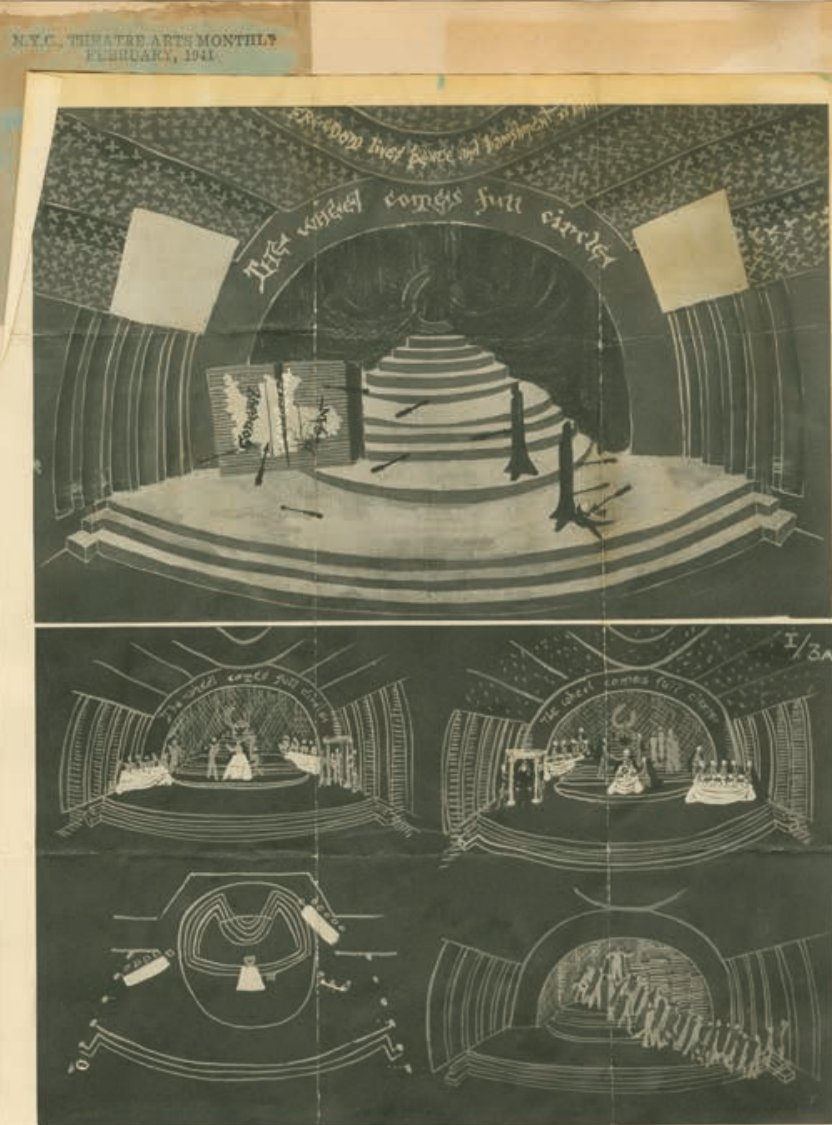

The lecture platform at the New School for Social Research, where Erwin Piscator presented King Lear, transformed into 8 spectacular stage by Antonin Heythum with a revolving stage backed by a grey fish-net cyclorama.
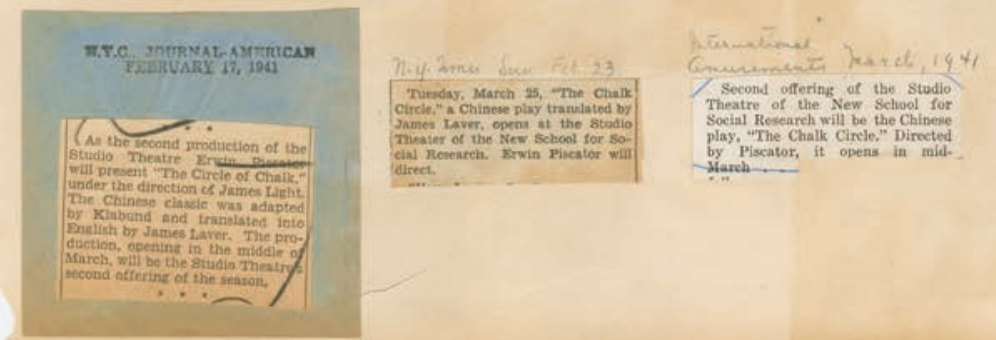

Fig. 2: Sketches documenting the scenographic development of the production King Lear, in: New York City, Theatre Arts Monthly, February 1942 (New School Publicity Office records. The New School Archives and Special Collection, The New School, New York, NY). 
pavillions (World Exhibition in New York, 1940; San Francisco, 1939; Paris, 1937; Brussels, 1935) and other thematic exhibitions in Prague. She also wrote or co-wrote articles for Architecture Forum and other publications. Charlotta Heythumová was one of only four women (and 33 persons in all) to receive a stipend in Czechoslovakia as part of the Refugee Scholars Programme of the Rockefeller Foundation.

The New School for Social Research in New York was Heythum's only pedagogical foothold in the US. Archival records ${ }^{8}$ suggest that in 1941 Heythum moved from New York to California, where he taught at the Californian Institute of Technology probably till the end of the war in 1945. This position offered to him was a chance to launch an experimental programme in Industrial Design based on 'Design Analysis' (PULOS 1990: 169). Arthur Pulos cites Heythum's standpoint: 'The need for technologically trained designers [...] makes the technological institute a more adequate place for industrial design training than an art school can ever be' (PULOS 1990: 169), and comments:

Heythum and his students had access to Caltech's research in time and motion and in human factors. But whereas the goal of such studies in wartime was the use of machines with maximum efficiency by human beings (in other words, putting the machine before the human), Heythum's goal was the inverse - putting human interest before the machine. (PULOS 1990: 169)

What Heythum's teaching of Industrial Design looked like is evidenced by the Bulletin of the California Institute of Technology:

ID 11lab. Design Trends. 1 unit (1-0); first semester. A survey of how the designer and the artisan in industry, in their recent products, have interpreted and answered the needs of the public. Instructor: Heythum.

ID 20lab. Industrial Design II. 7 units (2-15), first semester; 8 units (0-24), second semester. Selected advanced problems in industrial design and a major problem assigned individually to the student, giving an opportunity the encouragement for the exercise of personal initiative in the solution. This class is conducted as a seminar. A number of selected 24-hour problems and two major ones. The second semester is devoted to thesis work. Instructor: Heythum, in first semester. Second semester, Heythum, members of the faculty, and visiting experts. (Bulletin of the California Institute of Technology)

During the war, Heythum continued publishing articles on industrial design, concerned in particular with philosophy, purposefulness and aesthetics of this arts-industrial discipline (HEYTHUM 1940, 1942). It is not yet known when he stopped teaching at Caltech; some sources give 1944, others 1945. However, during 1944 he started lecturing at Columbia University in New York and his position at the California School 
of Design was taken up by his former students Salvatore Merendino and Harry R. Greene, who further explored the principles of his conception of the discipline and trained a number of leading postwar US designers both practically and theoretically. There is evidence that Heythum's links with Columbia University started as early as 1941, when Columbia University hosted an Exhibition of Work of Antonin Heythum: Stage Design, Architecture in its School of Architecture (in Avery Hall, between 24 April and 3 May 1941). This exhibition was accompanied by a print entitled The Work of Antonin and Charlotta Heythum; clearly, both the Heythums had their work in the exhibition. In 1944, Heythum was invited by Columbia University to deliver a lecture series named Design Analysis Course.

At this time, Heythum collaborated with the visionary artist Norman Melancton Bel Geddes, a scenographer active in Los Angeles, in the Metropolitan Opera in New York, as well as a costume designer for Max Reinhardt. He also excelled as a photographer, director and fashion designer. In 1927, Bel Geddes opened a studio of industrial design, offering futuristic products of supreme aesthetic and functional quality. Among his renowned products were a cocktail set, a futuristic car, a Toledo scale, a Philco radio cabinet, typewriters, cigarette cases, kitchen ranges, poleless tents and even battleships. The extent of Heythum's involvement in Bel Geddes's studio is as yet unknown but he was probably active on the design of the radio cabinet.

During 1944 the Heythums started to collaborate as designers and consultants with the progressive radio-making company Hoffman Radio Corporation in Los Angeles, and had a share in the creation of a range of tabletop models and inbuilt radios, as evidenced by the following article:

Packaging, an important element in the sale of any product, has come in for a major overhaul in the course of these 'night out' meetings. Antonin and Carlotta [sic] Heythum, leading designers of prewar Prague and now leading the industrial design activities at California's Institute of Technology, are among the designers creating a complete line of table-model and combination radios for the Hoffman line.

[...] An extensive consumer and dealer survey indicated many changes that should be made in the construction of radio cabinets. These have been incorporated into the Heythum's design and have resulted in radio sets with 'silent selling' features the radio dealer has long looked for. The present boom in records has not 'been overlooked' [...] in this blueprint of the future. Hoffman has stressed the importance of absolute perfection in manufacturing recording and play-back equipment. Consumer advertising will stress this advantage of the Hoffman set. (Radio Retailing Today 1944)

After the war until his death (1949-1954), ${ }^{9}$ Antonín Heythum in the position of Head of Industrial Design led the Industrial Design Atelier at Syracuse University (Syracuse, Onondaga County, New York State). His activities are considered foundational for the discipline within the USA. 


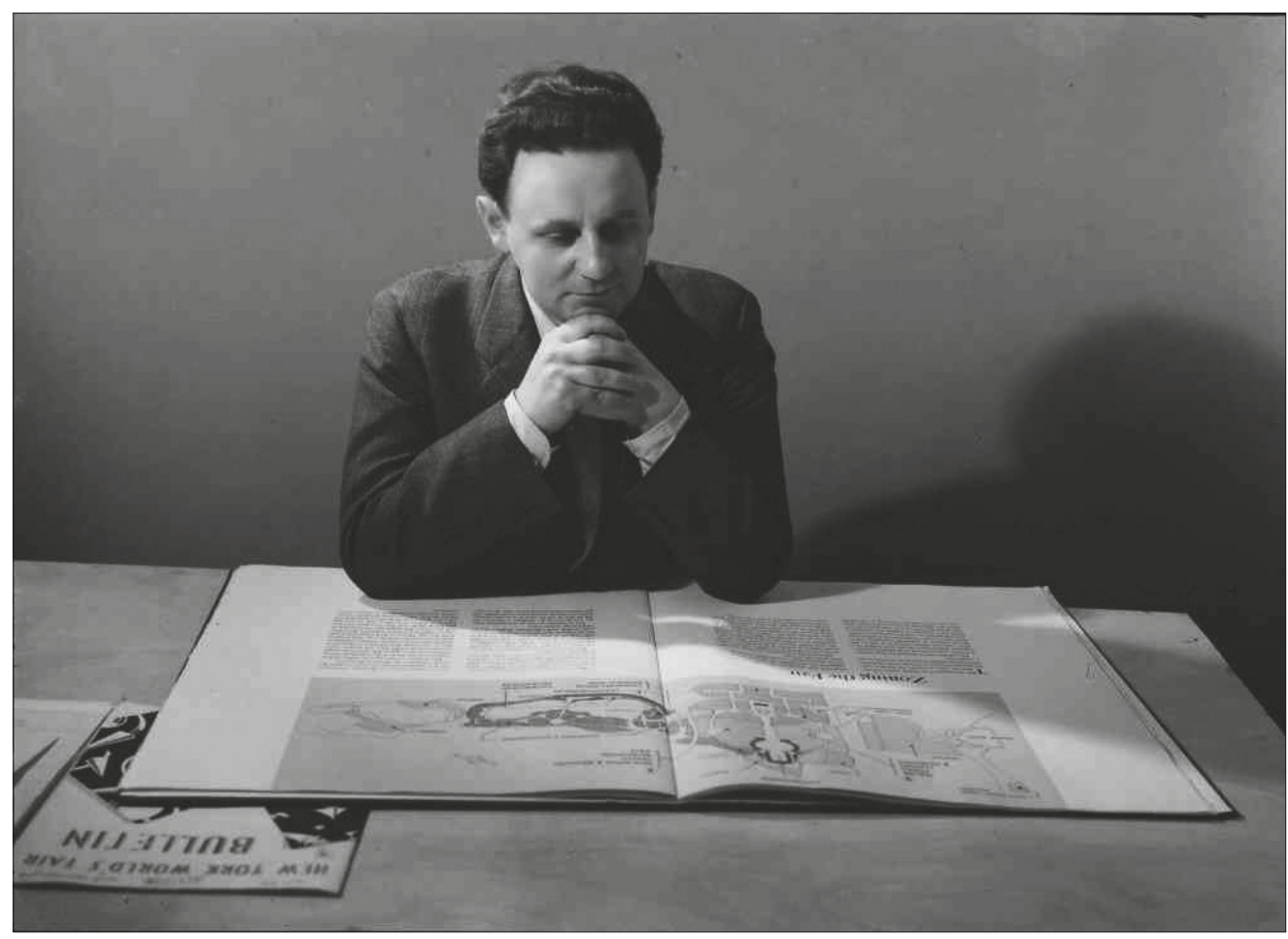

Fig. 3: Antonín Heythum with the project of the New York World's Fair 1939, photo from 1938 (Private Collection of A. Heythum's family).

During their early years in the US, the Heythums made contact with a number of renowned modern artists, among them Charles and Ray Eames and Alexander Calder. ${ }^{10}$ Charles Eames also taught at Caltech, where they could have met. ${ }^{11}$ Most notably, their closest wartime friends were Man Ray (Emmanuel Rudzitsky) and his that-time partner and later wife Juliet. Man Ray's diaries contain several pages referring to their Sunday talks; there is also a particularly interesting drawing and photograph that evidence an inspiration by the Heythums and a number of letters (edited by Jennifer Mundy) bear witness to the close friendship as well as mutual artistic influence the two couple had on one another.

Perhaps the most interesting testimony of the friendship is Man Ray's visual composition entitled Inspiralation, a name playing upon the words inspiration and spiral, and showing the renowned French gothic structure of the island monastery and church of

10 See for instance: Centre Pompidou, Paris, Bibliothèque Kandinsky, Collection Alexander Calder; letters written by the Heythums from Pasadena 1940-1944, and notes on Heythum's and Calder's collaboration in 1942 (pp. 4ff.). Available online at: https://www.centrepompidou.fr/cpv/ressource.action?param. idSource=FR_DO-55c1ec399e7d48433225fdf995 cbe76\&param.refStatus=nsr

11 The Library of Congress holds, for instance, a Christmas card from 'Antonín and Charlotta Heythum' to Charles and Ray Eames, Created 1946. Library of Congress. Control Number 2004676697. 
Mont Saint-Michel with an inscription 'Go to St. Michael holding an egg in each hand and your physical and spiritual desires will be satisfied' (MUNDY 2016: 239).

'The Inspiralation' was dedicated to, and made as a present for, Charlotte and Antonín Heythum, a couple with whom Man Ray and Juliet were close friends during the war years. ... Juliet later recalled that she and Man Ray would drive out to Passadena to see the Heythums every Sunday 'to talk about things'. (MUNDY 2016: 238-239)12

Man Ray's avant-garde experiments are recognised as a significant contribution to the history of photography: his object-based and abstract visual compositions were mostly created without a camera, using the sensitive layers of photographic paper. Technologically, in his 'photograms', Man Ray used shadow-based images created by placing compositions of objects with different levels of translucence onto a photographic paper under a source of light in a dark room. On exposition and developing, the resulting picture was a dark background with grey and white shapes standing out. The leading Czech avantgarde artist Karel Teige was a great admirer of these 'rayographs', as they were called, celebrating them as visual poems. Jaroslav Rössler was among the first Czech artists who created impressive photograms on principles derived from 'rayographs'.

\section{King Lear}

During 1940, when Heythum taught at the New School of Social Studies in New York, he also collaborated on a remarkable production of King Lear. In May 1939, Alvin Johnson, President of the New School for Social Research, signed a contract with theatre director Erwin Piscator with a plan to establish a theatre and acting school at the New School. For Piscator, arriving in New York and deciding to stay in the US, 1939 was a tasking year. He was severely affected by the suicide of the dramatist Ernst Toller (1893-22 May 1939) in 22 May, and perhaps even more by the death of his former partner and wife Vera Yanukova (1940-12 May 1939).

The Dramatic Workshop started its activities on 15 January 1940 with some 20 students. In September 1940 the Worksop launched semi-professional production work as part of its Studio Theatre. The premiere of Shakespeare's King Lear took place in mid-December of the year. On 17 November 1940, Piscator gave an interview for The New York Times, explaining the ambitions behind the studio stage:

[This] new company, made up exclusively of professionals, will provide a testing ground where, freed from the ordinary restrictions of the box office, important plays, both new and old, which are pertinent to our times may be produced, where new artistic values may be tested,

12 There is an image of the Inspiralation on p. 236 of this volume. Available online at: https://books. google.cz/books?id=vWtdCwAAQBAJ\&pg=PA238\&lpg=PA238\&dq=charlotte+heythum\&source=bl\&ots=xhr wrhUuiI\&sig=59uoFOEdV5GOq7wT5tcz45qVVew\&hl=en\&sa=X\&ved=0ahUKEwjuvMippOLSAhWDjCwKHf

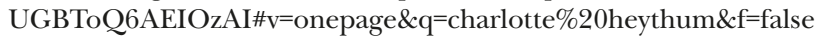


where values may be reaffirmed, and where fresh new talent may be discovered for the American stage. The question may well be raised, Mr. Piscator continued, why in a time like the present we should dare to launch a new theatre. 'But it is precisely in times of universal destruction that the artist must seek to discharge his debt to society by seeking to rebuild what is being lost, to what is transitory, to regenerate what is of true value and hold on to what is indestructible. We propose then a theatre of ideas, a joint venture of performers and playgoers alike.'

To the playgoer will be offered an active role in the Studio Theatre. He will be a responsive collaborator in its practical work; he will read the play before its performances, attend lectures by the staff of the Dramatic Workshop, participate in the cast's first reading, see a regular and a dress rehearsal of the play. The students will likewise be part of the enterprise. (PISCATOR 1940)

One of the contemporary students recollects:

So, in the fall of 1940, the Dramatic Workshop established its Studio Theater. In its first performance 'King Lear' Sam Jaffe played the title role, in the company of other professional actors. Our students played minor parts and assisted in the production under the supervision of the distinguished Czech designer Antonin Heythum, the lighting expert Abe Feder, the composer Henry Cowell, and Stevens Institute's innovator for theatrical acoustics Harold Burris-Meyer.

As a number of articles published in the autumn of 1940 suggest, the opening night of King Lear was planned for 6 December 1940 but it became clear in the course of November that this was too early and the premiére was moved to 14 December.

In the printed notes, Erwin Piscator introduced the audience to the mission of the new theatre company:

THE STUDIO THEATRE of the New School welcomes you to its first production in the theatre you are helping to create - an experimental theatre striving to develop a fundamental art. It has chosen King Lear for the timelessness of its theme, acute again today, and for the challenge it offers to production. It is a working theatre, presenting plays in progress not once and for all, complete in every detail. Its function, its opportunity is to work with a play intimately, intensely, then to live with it permanently as it becomes enriched by the perspectives of time and change.

THE STUDIO THEATRE conceives itself to be a center for actors and actresses eager to develop their art beyond the accidents of jobs; for technicians working toward new solutions; for playgoers with a personal relation to the theatre and its artists, willing to assume the responsibility of study and criticism of the play presented. To the future actors, directors, playwrights, designers, studying in the Dramatic Workshop, the Studio Theatre offers invaluable apprentice experience nearly impossible to obtain elsewhere in any coordinated way. Briefly these are the purposes of the Studio Theatre. 
Piscator also appealed to the audience:

We thank you for helping us to achieve them by being here tonight. Will you help us further by filling in and returning to us the questionnaire you will receive at the end of the performance. (Programme Notes in the New School's Archives)

My inquiry is directed mainly at the scenographic aspect of the production; however, it is noteworthy that the creative team comprised leading artists of the era:

STAFF OF THE STUDIO THEATRE

ERWIN PISCATOR, JAMES LIGHT, MARIA LEY

Technical Director HANS SONDHEIMER

Consultant on Stage Design ANTONIN HEYTHUM

Lighting by FEDER

Sound by HAROLD BURRIS-MEYER

Costume Design CHARLOTTA MALECKA-HEYTHUM

Choreography for Fool's Mummers by LOTTE GOSLAR

Fool's Puppet designed and executed by ERIC GORT

The list printed in the programme notes omits Henry Cowell (1897-1965), a leading US avant-garde composer, who had had contact with the Czechoslovak musical scene (visiting Prague and Brno, meeting with Leoš Janáček in 1926) and was an influential teacher too (teaching John Cage among others).$^{13}$ Cowell's incidental music for King Lear was composed for male chorus, piano and symphonic orchestra, as his archives suggest, and completed on 2 December 1940: '[F]inished 21 short pieces for King Lear.' Four days later he adds: 'Music for King Lear is finished, rehearsed, and recorded.' ${ }^{14}$ Cowell led music courses at The New School of Social Research. The Curriculum lists a course of Creative Music in America (No. 101; listed on p. 63) and a Workshop in Musical Theory (No. 106; p. 65).

The dancer Lotte Goslar (1907-1997), listed in the programme notes as the choreographer, had toured Europe with Die Pfeffermühle cabaret in the 1930s and was also known well in Prague. She made a successful appearance in Jiří Voskovec and Jan Werich's Liberated Theatre production of Balada z hadrü [A Ballad in Tatters] in 1935. In autumn 1936 she visited the US and in 1937 decided to stay there in exile, running the successful Lotte Goslar's Pantomime Circus. Jarka M. Burian, in his essay on Voskovec and Werich's career in the US, offered a fascinating suggestion; Voskovec and Werich probably obtained the necessary US visa only thanks to a ruse of William Morris, director of an influential agency: 'Apparently it was through the efforts of Lotte Goslar, a talented German mime and dancer who became well known in America. She [...] persuaded Morris of their reputation and talent' (BURIAN 1939). In her memoirs,

13 See (ŠTĚDROŇ 1998: 123-124). I am grateful to Pavel Drábek for drawing my attention to this connection.

14 The catalogue of the Cowell archives is available online at: http://www.henrycowell.org/hc/sf002/ catalogNp182.cfm?CFID=217857000\&CFTOKEN=91935398\&jsessionid=84305d95662062e98cfc49772d2e4a173ef7, No 606. King Lear 


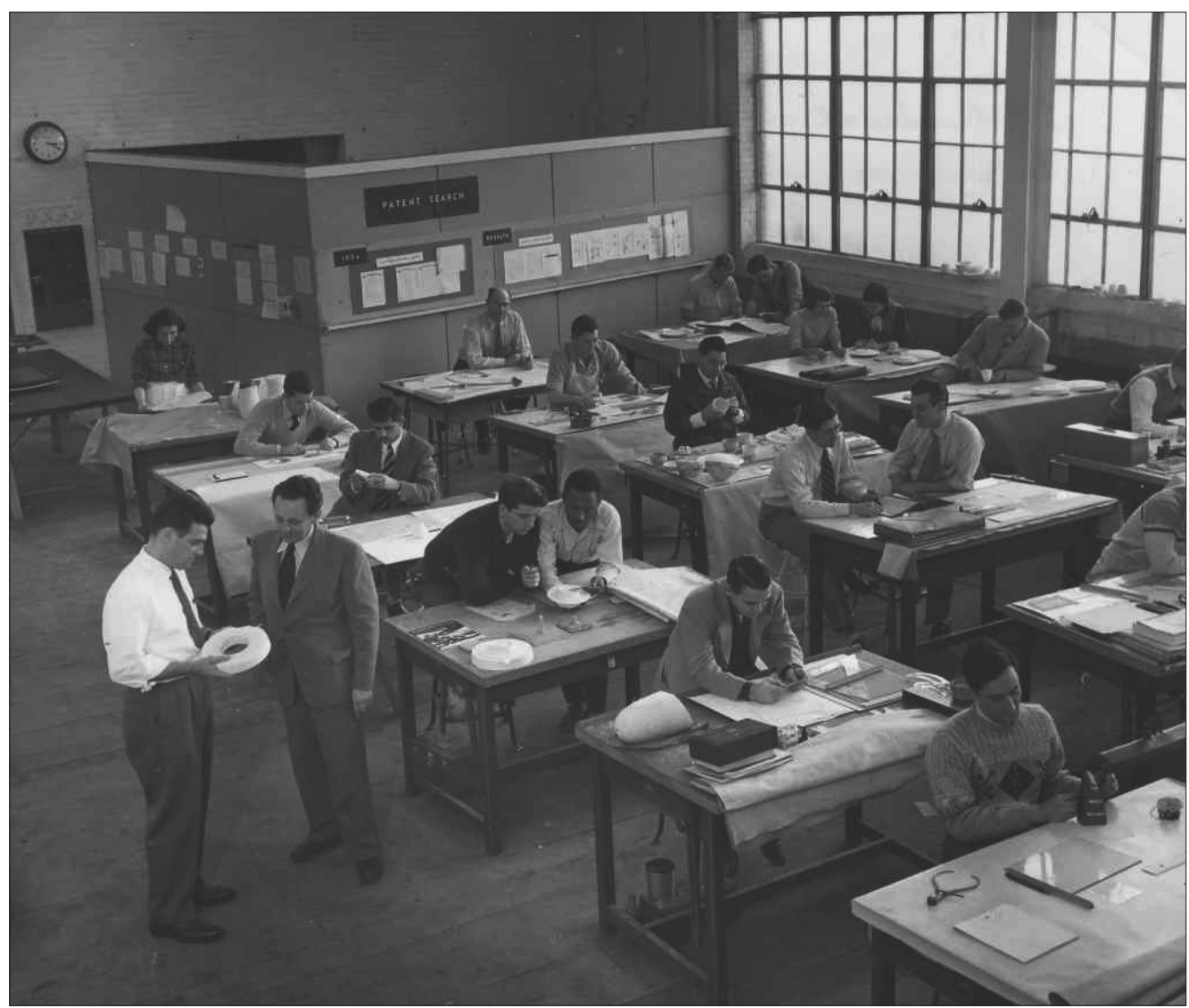

Fig. 4: A drawing office for students, the Industrial Department at Syracuse University, A. Heythum is the second standing man on the left

(Private Collection of A. Heythum's family).

Goslar notes: 'Erwin Piscator asked me to create a "Mummers Dance" for his "King Lear" production with Sam Jaffee at the New School' (GOSLAR 1998: 54). This brief mention suggests that there was a 'Mummers Dance' (or, as the programme notes call it, 'Fool's Mummers') very likely towards the end of the show, probably inspired by tradition folk amateur theatre masked dancing representing fights, although its exact form cannot be ascertained. Clearly it was meant to be a grotesque entry. Lotte Goslar was not only the choreographer but also one of the dance company. The dance piece may have incorporated the puppet of the Fool, designed and made by Eric Gort. Most reviewers of the production did not think highly of the choreography. This is unsurprising since most of the reviews also made ironic comments about the other scenic experiments and mocked the avant-garde practices: 'Lotte Golsar and her eccentric dance group strike an incongruous note' (COLEMAN 1940a), or: 'Her dance group, who erupt to do a grotesque number that is dull and embarrassingly unfunny' (BURR 1940). 
The severest appraisal was brought by John Anderson in the N.Y.C. Journal:

When the king sends for his fool, he gets not only the sort of echt Deutsch black tights-jester via Werner Kraus-cum-Caligari, but Miss Lotte Goslar and a bevy and sock footed putty nosed dance mimes, who go through a dreary piece of heavy-witted burlesque. (ANDERSON 1940)

Abe Feder's lighting design was praised by several reviews as of high quality, while the sound effects by the innovator of theater acoustics in the Stevens Institute, Harold Burris-Meyer, were looked down upon with scorn:

Harold Burris-Meyer's sound effects may be mechanically ingenious, but when they project the voice they debase it with a metallic note, and when they are invoking the eeriness of the fates they sound like nothing so much as a heavyfreight-car squeaking on a rusty siding. (The Play, Piscator Stages a Production of King Lear with Sam Jaffe in the Title Part New York Times 1940)

The little photograph of the scenic design sketch discovered initially in the Thompson Library, undoubtedly made by Antonín Heythum, is not very good but still bears legible inscriptions and makes it possible to interpret the design and at least partially understand its intended function..$^{15}$ The sketch is made in black ink and the groundplan makes it clear that a revolve was intended, or a circular stage at least. ${ }^{16}$ The right hand side of the revolve shows two bellows with Heythum's handwritten note: 'Battery of Blowers operated by hands of orchestra members.' At the level of the right hand portal is drawn a 'Large sheet of metal screen for metallic reinforcement of Lear's voice.' From the figure portrayed centre stage, probably King Lear, there are two lines towards the metal screen, one of them reflected towards the audience. This indicates the direction of the words spoken by Lear. In the axis of the revolve the portal has a projector and a segment to project the film on, tagged as 'King's Lear projector (film).' The left hand side of the design cites lines from Shakespeare:

Blow, winds, and crack your cheeks! rage! blow!

You cataracts and hurricanoes, spout

Till you have drench'd our steeples, drown'd the cocks!

You sulphurous and thought-executing fires,

Vaunt-couriers to oak-cleaving thunderbolts,

Singe my white head!

This is from Act 3 Scene 2, the storm scene on the heath with Lear and the Fool. Lear delivers the famous expressive monologue of despair. The sketch suggests that Heythum envisaged the use of fabric drapes of different colours to be freely swayed by

15 I would like to thank Cole Luke, assistant in the Thompson Library Study of Ohio State University, who helped me decipher the small lettering on the photograph (15 February 2017).

16 Thompson Library, Special Collections, Collection of Jarka Burian, Heythum 84060 31; the felt pen margin reads: 'Heythum, Lear'. 
the blowing of the bellows. Abstracting from his previous designs the sketched groundplan would also expect two standing (or suspended) slightly bent structures to hang the streamers on (as was the case with his 1931 design for The Merchant of Venice at the National Theatre in Prague). The sketch suggests that Heythum made use of effective shapes well known from his set designs for Olomouc and Prague; these were in particular his work with drapes (streamers) that were meant to accompany Lear's famous monologue.

The upstage area of the scenic space was to have an s-shape, a feature known from Heythum's scenography for Tannhäuser; a refined work with the revolve was intended (previously used in Todo is an Outsider or The Spring of Nations); and judging by the lights, the intention was to use an enlarged cast shadow (Cirkus Dandin; Doña Sancha). His fascinating use of spotlight and projection, previously deployed in his grand opera designs, was to be applied again in King Lear. The sketch itself does not answer the question how the stage space and its changes worked in King Lear. This required further research.

The drawings published in New York City Theatre Arts Monthly ${ }^{17}$ allow a more accurate reading and reconstruction of the final form of the scenic object and the individual scene changes. Judging from the handwriting, these drawings were made by someone other than Heythum and they document the completed production. They are not scenic designs as is the case of the sketch. The scenic object reminds of a terraced mastaba (pyramid); its groundplan has the shape of an irregular flattened semicircle mounted on the revolve; the turning of the object achieved changes in the scenic images. The space was divided in depth into two parts by a semicircular portal: the inner stage above the revolve, and outer one protruding towards the audience. The access to the rotund platform was by two steps.

The printed picture suggests that for most of the show (probably with the exception of the final scene) the stage was decorated with an inscription placed on the semicircular stage portal, written in gothic capitals: 'The wheel is come full circle (I am here),' citing Edmund's line from the conclusion of the play. The opposite arch bore a second inscription in gothic capitals: 'Freedom lives hence and banishment is he[re],' citing Kent's line in the opening scene of the play. This inscription, belonging to the first half, is accompanied by screens placed on the left, showing the map of the kingdom, divided into two, with Goneril's name on the left and Regan's on the right. The rift between them is filled with the name Cordelia. To the right of the stage were two objects representing probably burnt tree trunks and there were seven arrows lying on the terraces of the scenic structure, with another three stuck in the map. Above the centre of the build a circle was suspended (or attached in some way) and to it was fixed a massive drapery made of grey netting. The caption refers to a 'grey fish-net cyclorama'. Whether this was actually an infinite abstract backdrop (cyclorama) or whether the grey net had a different purpose, cannot be safely ascertained. Surely the net created a neutral backdrop. The drawings suggest that roll-up rags or blinds were also used; in the second and third

17 New York City Theatre Arts Monthly (February 1941); unidentified clipping; Archive of the New School. 
scene change they concealed the niches on the sides of the portal, and in the last scene change they served as four stage drapes covering the right hand depth of the stage.

Four stage props: a rectangular portal, a 'throne' and two oblong 'tables' were located onstage and, when the stage revolved, they were used in their mirror formation. In the first scene, the arched portal was equipped with two white square surfaces, probably serving as projection screens.

All these drawings also show distinct side entrances (or niches) to both sides of the stage and certain striking arches above the portal; their purpose is unclear and I have been unable to interpret what their meaning was. ${ }^{18}$

The last resort was to search for the actual venue of the experimental Studio Theater stage where Heythum realised his scenography. Today, the venue is known as the Tishman Auditorium (at 66 West 12th Street, New York) and the photographic documentation of the interior suggests that the architecture probably had a key influence on the form of Heythum's stage object. The theatre was designed by architect Joseph Urban (1872-1933), who had designed also the Paramount Theatre at Palm Beach in Florida (1926), the Ziegfeld Theatre (1927), the International Magazine Building (1929) in New York City, as well as Heythum's workplace in New York, The New School for Social Research (1930). The architecture of the interior is remarkable for its use of a sizable rotund space in Art Deco style. The groundplan has an oval shape, with the stage located in the narrowest end. It is divided by a semicircular portal (proscenium arch) with five angular niches (arcades) appended to it. The ceiling is also rotund and its terraced segments surely inspired Heythum's stage object. The dominant colours of the theatre's interior are grey and red; red is used on the narrow sides of the ceiling segments and on the carpets in the aisles. Unfortunately, only black-and-white photographs, the above-cited drawings and the original sketch are available; it might have been the case that the colours of the scenic objects also corresponded with the interior. Of importance is also the stage floor protruding towards the audience. The drawings suggest that the entire stage floor covered the space between the lit 'arcades' and reached as far as what was later the fifth row of the auditorium. It can be assumed that the contact between the spectators and the performers may have been intimate. The theatre's interior also suggests that not only the fixed proscenium arch was used for scenic purposes but also a segment of the auditorium ceiling with the above inscriptions: 'The Wheel...' on the semicircular portal, and 'Freedom Lives...' on the rotund segment of the ceiling. It may also be that both the inscriptions were projected onto the surfaces.

Thanks to the kind help of the New School's Archive, a number of details of the production of King Lear and the other theatre activities can be gleaned from the newspaper clippings. ${ }^{19}$ The preparation process of the production can be traced in great detail.

18 A clipping with a picture (N. Y. C. Theatre Arts Monthly, February 1941) is accompanied with the following inscription: 'The lecture platform at the New School for Social Research, where Erwin Piscator presented King Lear, transformed into a spectacular stage by Antonin Heythum with a revolving stage backed by a grey fish-net cyclorama.'

19 Archives \& Special Collections, The New School Libraries and Archives, 66 Fifth Avenue, Lobby Level, New York, NY 10011. Special thanks go to Ms Liza Harrell-Edge. Unfortunately, with a number of reviews only the original periodical and the publication date can be identified but not the pagination. 
Logically, most articles are interested in the figures of Erwin Piscator and the main actor playing King Lear, Sam Jaffe. In the numerous interviews Jaffe gave he mentioned that 'his' opening night was planned for 6 December $1940 .^{20}$

I don't want to think about Hollywood right now. I hope I don't get an offer from them. I'm too interested this new stage job of mine. [... As a concept for the production Jaffe mentioned] those who degrade another degrades himself.. ${ }^{21}$

Interviewed by Inge Benson, Jaffe refers to Piscator's plans for a cycle of productions that was to be launched by his King Lear:

This is the way it was. But what is this plan? Well, to many it is many things. To the cognoscenti it is an evolutionary unfolding of events in a factual, documentary manner. It is a cycle without the cyclic restrictions. To Piscator it is 'the manner of presentation that says to an audience: "this is what really happened; this is the way it was."

'Every player has certain pet parts he sees in a very personal light,' Jaffe said. 'It has been my ambition to present Lear as a human being caught within the very same elements of social strife that confront us today. Dictatorship was a very common failing in Lear's time just as it is today. And the old King grew into the tyrant through boundless just for power and more power. That is the pattern for "King Lear" and I and Mr. Piscator see it.' (BENSON 1940)

It was probably on 29 November 1940 that it was decided to move the date of the opening night. On that day the N. Y. C. Telegraph wrote:

Henry Cowell, the modernist composer, is writing an incidental score for Erwin Piscator's production of 'King Lear', which opens at the Studio Theater in the Dramatic Workshop on Saturday evening, December 14.

This marks one of the rare times when this outstanding modernist composer has accepted an assignment to write a score for a drama. Following his Guggenheim fellowship in European folk music, he returned to New York and later joined the music staff of the New School. (GORDON 1940)

An early extensive, though unfortunately not very positive review of the production was published in The New York Times on 16 December 1940:

Not being exactly a traditionalist, he has staged 'Lear' in the wideflung, sculptural style that breaks down all the representation scene barriers of the conventional theatre and makes way for

20 N. Y. C. Journal of Commerce (October 30, 1940); New York City News (November 1, 1940); The Morning Telegraph N.Y. (November 4, 1940); Robert Coleman. Sam Jaffe Has Title Role in Piscator's King Lear. New York City Mirror (October 30, 1940); King Lear will be played at New School Tonight. New York City Herald Tribune (December 14, 1940); and another 20 clippings.

21 Actor Jaffers 'NOT IN' TO FILM OFFERS - Right Now He's Too Absorbed In 'King Lear' Experiment. Philadelphia PA. Record (November 17, 1940). 


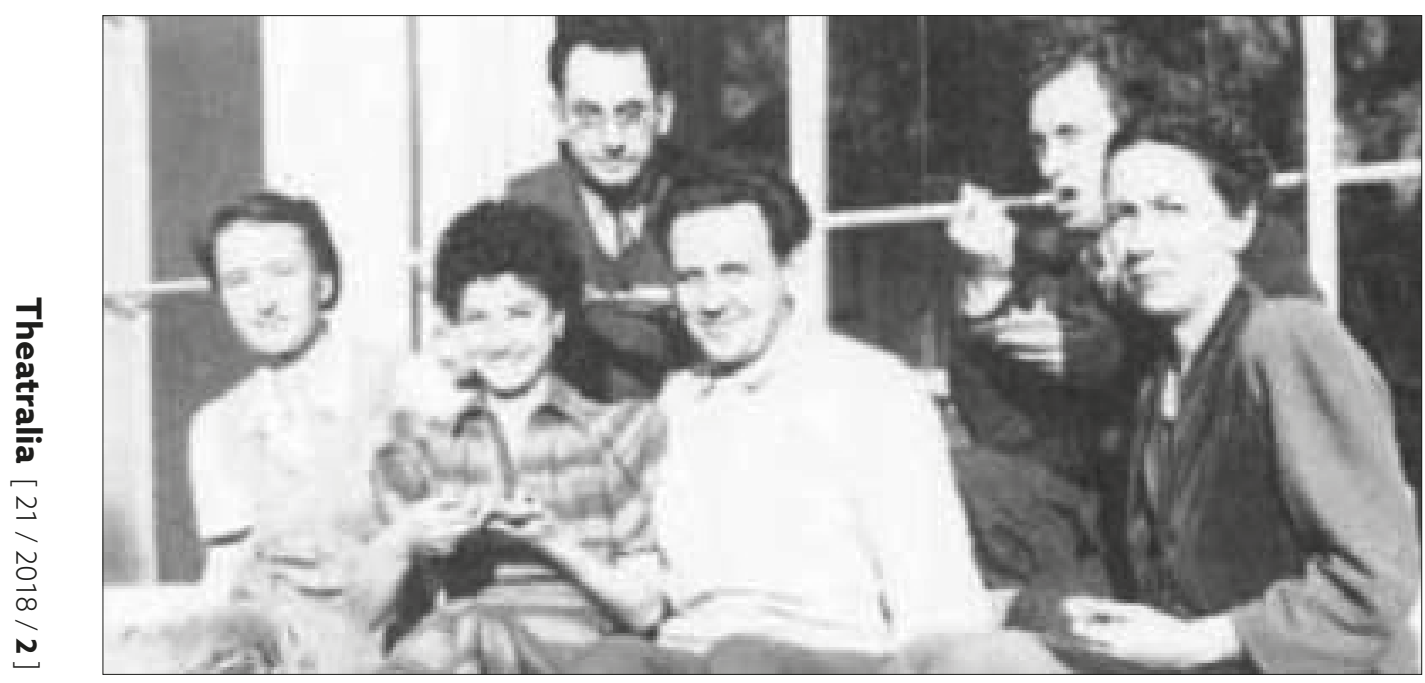

Fig. 5: Bottom row, left to right: Charlotta Heythum, Juliet Browner (later Ray), Antonin Heythum, Jean Harris; Top row, left to right: Man Ray, Harwell Hamilton Harris (Germany, Lisa. Harwell Hamilton Harris. University of California Press, 2000: 89).

the 'dynamic theatre' [...] There is no curtain. A series of long platforms lead up to a pyramid of circles center stage. The actors enter through portals on either side or down the aisles of the auditorium and play on various stage levels according to the significance of the scenes [...] The functional style of stage production makes for remarkable fluidity of narrative treatment. By virtue of Feder's excellent lighting, it also discloses some dramatic pictorial groupings of action in costume. But no matter what stage arrangements a director may be making, the intelligibility of a performance of Shakespeare depends upon the skill of the actors and the skill the director has for moulding a design out of their playing. In these two respects this 'King Lear' Is painfully wanting [...] For Mr. Jaffe lacks talent for Shakespeare [...] Even if the actors were all of first quality, there is little evidence that Piscator could stage 'King Lear' as a dramatic poem of tragic ferocity. For the performance is loose and flabby and the emotion is exterior. Although the functional stage is supposed to liberate the drama from a load of dead impedimenta, it has its own way of impeding the drama. The beating of many feet on the hollow platforms of the stage, the constant climbing and descending and the laborious turning of the revolving stage gradually cease to have dramatic meaning and become increasingly tedious [...] There is never a substitute on any stage for intelligent acting, honestly directed in the service of the author. Let us not forget that the author of 'King Lear' is William Shakespeare, a poet. (New York Times December 16, 1940).

John Anderson's review for the N. Y. C. Journal openly mocked the stage effects, the distortions of Lear's voice, and even called the onstage object a 'lopsided wedding cake' (ANDERSON 1940).

A somewhat more positive review was published by the N. Y. C. Wall Street Journal (16 December 1940) but even here the shortcomings of the leading performer are mentioned: 
In the Dramatic Workshop of the New School Erwin Piscator has fashioned a production of one of Shakespeare's most difficult plays. It is frankly an experimental presentation, and in the light of this approach there is a goodal to report that was interesting. Viewed as a finished professional work, despite that, fine effort of Sam Jaffe, it lacks a good deal. The Studio Theatre, following the performance, hands out questionnaires to the members of the audience to determine their reaction to various features of the play, and a discussion of the play, which this reporter was unable to attend, was held fifteen minutes after the performance ended. This discussion might have proved more illuminating than the play itself, for the Studio Theatre seems to be laying more emphasis on technique and interpretation than on performance. It remains this reviewer's conviction that all the novelties in the world cannot make up for mediocre acting, and it was this law which was the most serious one.

John Mason Brown, in the New York City Post, slated the production but thanks to his description of scenic details, his review is helpful in reconstructing the form and progression of the production. For this reason, I am quoting a long extract:

No wonder Lamb spoke derisively of the theatre's contemptible machinery by means of which designers must seek to mimic the storm in which the old man goes out. Or insisted actors might as easily propose to personate the Satan of Milton or one of Michael Angelo's terrible figures. For 'King Lear' is a great play that is too great for the stage. Theatrically this may be a part of the play's tragedy. But in the library it is a proof of its glory. Because the greatness of 'Lear' is a greatness which lies beyond representation. Its words are as torrential as the storm on the heath. They need no voices to unleash their thunder. They tolerate none. They strike their terrible music in the imagination without being heard. Brilliantly done, 'Lear' would leave much to be desired. Done fairly well, the very adequacy of such a production would prove inadequate. But staged as Mr. Piscator has staged it, in a supposedly 'arty' manner and with some hopelessly insufficient actors, the play becomes an experience which would be laughable, if it were not so dull and dispiriting. Mr. Piscator, a well-known innovator in the German and Russian theatres when times were happier, has brought to his production all the external trickery once identified with the more advanced 'new stagecraft'. Ironically, however, nothing could seem more old-fashioned than his insistence upon novelties which, a decade or two ago, were exciting symbols of revolt.

\section{Poor Lear}

In his 'Lear' one hears not the howl of spiritual hurricanoes so much as the death-rattle of Expressionism, Constructivism, and all the other 'isms' which once enlivened the stage. His setting is a revolving turret, with steps, which keeps on swinging around like the Monitor caught in a whirlpool. Taking a cue from 'Gorboduc', and no doubt pointing to a social significance not elsewhere established in a production which threatened to 'King Lear' with modern dictators, Mr. Piscator opens the tragedy with some dumb-show. One scantily dressed man slays another scantily dressed man $[\ldots]$ 


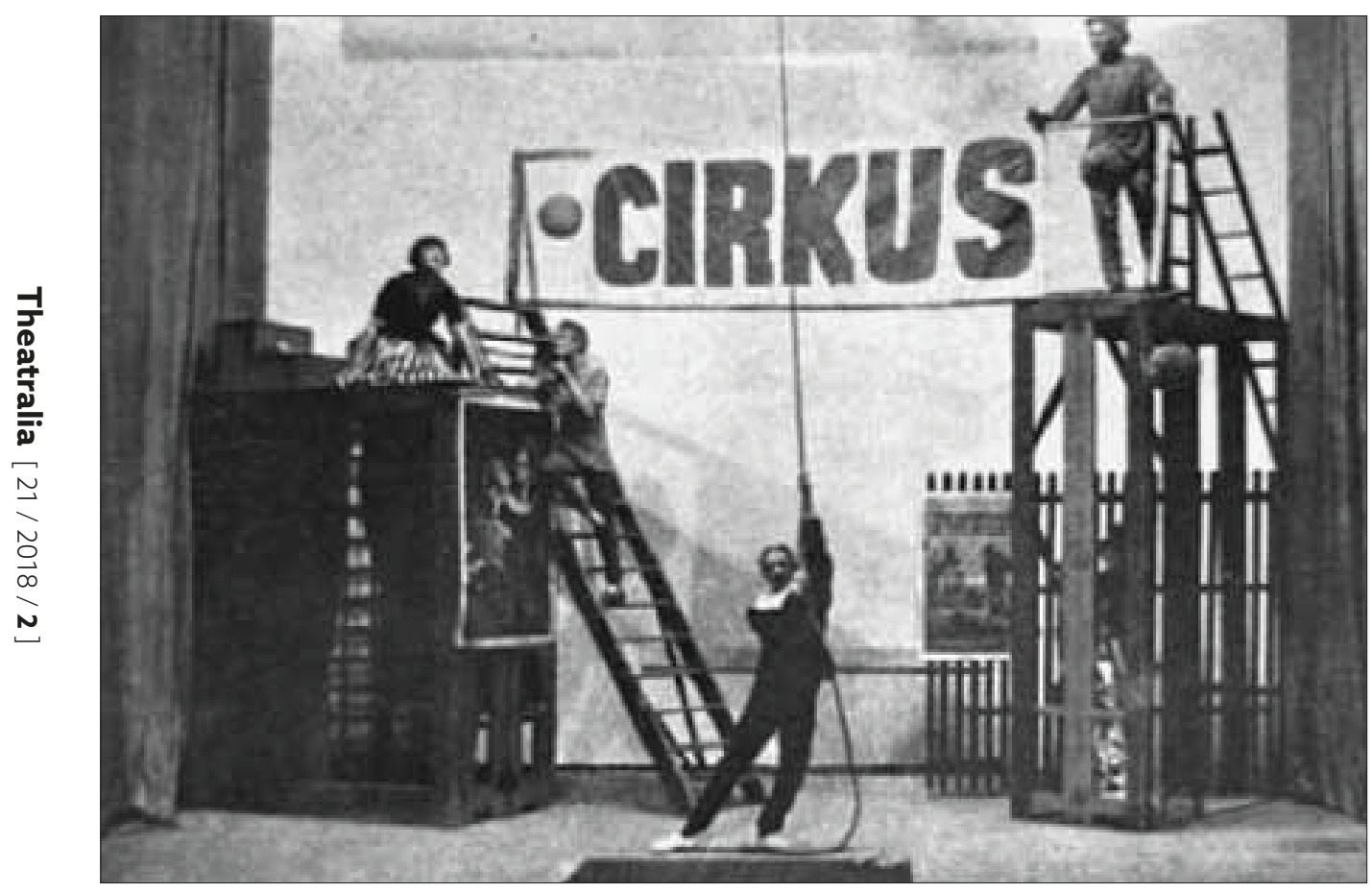

Fig. 6: Cirkus Dandin, Osvobozené divadlo, 1925. Available online at: http://www.phil.muni.cz/udim/avantgarda/index.php?pg=osvobozene_divadlo

Thereafter, under changing lights, before porch blinds carried in by supers, with much running up and down the revolving steps, and with many entrances from the aisles, Shakespeare's tragedy runs - in cut form - a more expected course. Yet while so doing, the resulting 'Lear' fares little better than the old king does at the hands of Regan [...] And the others (including the army of twelve supers who wear trench helmets which have been silvered) are not much better. If this production at the New School is 'King Lear' then a gold-fish bowl is the ocean during an equinoctial storm. No wonder, when at eleven-forty or thereabouts the old king had finally breathed his last, some of us felt like applauding Kent as he said of Lear: Vex not his ghost: O, let him pass! he hates him much. That would upon the rack of this tough world. Stretch him out longer. (BROWN 1940)

Robert Colleman's review also bears a pejorative flavour due to its title 'Newest "Lear" Like Children Using Firecrackers'. However, Colleman identified a few positive moments:

Piscator has arranged 'Lear' in two parts and added a sort of epilogue from 'Troilus and Cressida'. Part one is lengthy, wooden and unbelievably dull. Part two improves noticeably. It helps to dispel the mental fog induced the initial canto [...]

Piscator, we surmise, gave more thought to the physical rather than the histrionic aspects of 'Lear'. He and Antonin Heythum have devised a production that utilizes a four level, 
revolving stage and sound effects out of Walt Disney's 'Fantasia'. ${ }^{22}$ The stage rises seven feet to a plaster-like summit. Here Piscator poses much of the action, but the drama, paradoxically, seldom gets off the floor [...] After all, Shakespearian productions good and bad, must be encouraged if $[\ldots]$ actors are to develop the skill with which to reach the exciting peaks Shakespeare visioned. Practise makes perfect. Even great mountain climbers serve and apprenticeship. So let's charge it off to the worthy cause of experience. Hopefully yours, Bob Colleman. (COLLEMAN 1940b)

Finally, one of the few critics, M. Jagendorf, 'The Night in New York' columnist of the Sentinel, invited his readers to go and see Piscator's King Lear:

The play is far of perfect. But the unusual provocative staging, plus the many moments of great tragedy of setting and colour and sound is more then worth travelling down to 12th Street $[\ldots]$ but with the limitation of the stage it is an extraordinary performance and should not be missed anyone who loves Shakespeare. (JAGENDORF 1940)

In a positive sense, Richard Watts called the set a 'dizzily whirling stage' (WATTS 1940).

The first impulse for this essay was a photograph deposited in Jarka M. Burian's archive in the Thompson Library. It has become obvious that it most likely captures a sketch in an early phase of the development of the scenic form; this concept underwent changes during the discussions between scenographer Heythum and director Piscator, resulting in the remarkable terraced scenic object that corresponded with the theatre's interior. This was clearly the only scenography of note that Heythum realised during his exile in the United States.

The extant reviews suggest that the production concept was not very successful, being appraised as ridiculous, laughable and uncorresponding to Shakespeare's text. A number of critics made ironic comments on the dynamic imaginative, symbolist or expressive efforts, and observed that the star performer Sam Jaffe failed to meet the expectations. It can be assumed that the simplified stage form was ineffective for the US audience and perhaps too abstract. Still, there were a few critics who found appealing moments, in the musical, choreographic, or scenographic aspects. It might have been this failed production that contributed to Antonín Heythum's rift with the theatre in the US. It is known that he later collaborated as scenographer on a production called Women; of Clare Boothe Luce directed by Gilmor Brown in the Pasadena Playhouse Theatre, 1943.

Nevertheless, the discovered photograph of the sketch captures Heythum's remarkable scenic vision that crystalises an idea for a key scene of Shakespeare's play - in an abstract space, with the energy of the elements suggested by the use of a revolve, massive drapery, a blast of air from bellows, distorted sounds, projection and lighting. It

22 A month before King Lear, Walt Disney's Fantasia opened on 13 November 1940. This film has been seen as Disney's only truly timeless experiment, combining classical music and animation. 
transpires that Heythum continued in his earlier progressive stage experiments during his US exile, attempting a complete abandonment of realistic description and trying to achieve universal emotions and effects. It may be because of the lack of recognition from critics that Heythum did not continue in these experiments and dedicated himself exclusively as a pedagogue to the area of Industrial Design - with a particular focus on ingenious, practical furniture (working desks and spaces, kitchens, refrigerators, wardrobes, sinks, armatures etc.). ${ }^{23}$

As for Heythum's scenographic work, the last opportunity for the American public to see it was in 1967, during an exhibition hosted by the Carnegie Institute of Technology, held in the Hewlett Gallery, Pittsburgh, Pennsylvania (23 February to 3 March 1967). The exhibition brought a number of stage designs by the late Antonín Heythum. ${ }^{24}$

This article dealing with the theatrical production of King Lear, whose stage design was created by Antonín Heythum in the war period, considerably enriches our present knowledge of the work of one of the most renowned Czech scenographers. This graduate of architecture belonged among the most distinctive scenographers of the Czech theatrical avant-garde, primarily due to his entirely unique work with metaphorical stage objects, which he constructed mostly from wood, and due to his creation of variable stage spaces of screen type. By using a kinetic system, sophisticated and dramaticlooking spot lighting, projections and voice modulations, his stage design impressively influenced the whole production.

Within the poetics of changeability of meanings and the use of surprising metaphors, often inspired by children's games or the world of the circus, his objects, together with the action of actors, co-functioned associatively. The qualities, which made him a sought-after producer in his native country and which differentiated him from mediocrity, paradoxically did not find an adequate use in the United States. It could have been because of the abstract complicatedness of his expression, different associative connections based on cultural differences, or his tendencies for left-wing opinions. Still, the production of King Lear employed progressive stage methods and principles. By the war period, Heythum had designed eighty-two productions ${ }^{25}$ on domestic stages, especially in the theatres in Moravian Ostrava, Olomouc, Brno and Prague (Švanda Theatre, Red Seven, the Liberated Theatre, the National Theatre) and elsewhere. The knowledge of Heythum's work is so far only fragmentary and in the present is being thoroughly processed. Based on such new discoveries, to which belong the details of the production of King Lear, a new comprehensive portrait of the work of this distinctive artist will be created. Besides scenography, Heythum professionally dealt with designing the biggest international exhibitions, enhancing many modern interiors in prewar Czechoslovakia, participating in the production of furniture, engaging in industrial

23 HEYTHUM, Antonin. Industrial Design Section of the California Institute of Technology. Report of Activities, 1941-42, Minireview of California Institute of Technology (June 1942): 4-10; Bulletin of the California Institute of Technology 54: 4: 211. Available online at: http://calteches.library.caltech.edu/82/2/ES5.4.1942.pdf

24 Carnaige Institute of Technology. Community calender [online]. Available online at: http://digitalcollections.library.cmu.edu/awweb/awarchive?type=file\&item=386445; p. 4 . 
design and studio craft; he also wrote theoretical essays about architecture, gave lectures and organised exhibitions. All Heuthum's activities were always performed with great zeal, responsibility and in top-class quality.

\section{Bibliography}

Actor Jaffers 'NOT IN' TO FILM OFFERS - Right Now He's Too Absorbed In 'King Lear' Experiment. Philadelphia PA. Record (November 17, 1940).

ANDERSON, John. 1940. King Lear Staged by Studio Theatre: Sam Jaffe plays Title Role in Piscator's Production of Shakespeare Play, with Incidental Music. N.Y.C. Journal (December 16, 1940).

Archives of American Art, Washington DC, Antonín Heythum's papers.

BENSON, Inge. 1940. His Epic Plan, Workshop 'King Lear'. New York Herald Tribune (December $1,1940)$.

BROWN, John Mason. 1940. Piscator's King Lear with Sam Jaffe. New York City Post (December 16, 1940).

Bulletin of the California Institute of Technology, 54: 4: 211.

BURIAN, Jarka M. 1939. The Adventures of Voskovec and Werich in America, 1939. A manuscript essay, deposited in the archive of the Svět a divadlo journal. Published in Jakub Škorpil's translation at: http:/ / host.divadlo.cz/art/clanek.asp?id=9666.

BURR, Eugene. 1940. New School's Studio Theater Offers Piscator-Jaffe 'Lear'. Cincinnati Ohio Billboard (December 28, 1940).

Carnaige Institute of Technology. Community calender [online]. Available online at: http:// digitalcollections.library.cmu.edu/awweb/awarchive?type=file\&item=386445; p. 4

Centre Pompidou. Paris, Bibliothèque Kandinsky, Collection Alexander Calder; letters written by the Heythums from Pasadena 1940-1944, and notes on Heythum's and Calder's collaboration in 1942 (pp. 4ff.). Available online at: https://www.centrepompidou.fr/cpv/ressource. action?param.idSource=FR_DO-55c1ec399e7d48433225fdf995cbe76\&param.refStatus=nsr

COLLEMAN, Robert. 1940a. Sam Jaffe Has Title Role in Piscator's King Lear. New York City Mirror (October 30, 1940)

COLLEMAN, Robert. 1940b. Newest 'Lear' Like Children Using Firecrackers. New York City Mirror (December 16, 1940).

FREJKA, Jiří. 1925a. Rekvizita na jevišti a jevištní asociativní faktor [The Onstage Prop and the Onstage Associative Factor] Pásmo 2: 1 (October 1925): 10.

FREJKA, Jiří. 1925b. O konstruktivní scénu u nás [Towards Our Constructivist Stage]. Host 5 (1925/26): 61-62.

FREJKA, Jiří and HEYTHUM 1925. Spolupráce režiséra a architekta na divadle [The Director's and Architect's Collaboration in the Theatre]. Stavba 4 (1925): 5: 69-71.

GORDON, Will. 1940. King Lear. N. Y. C. TELEGRAPH (November 29, 1940).

GOSLAR, Lotte. 1998. What's So Funny?: Sketches from My Life. London: Routledge, 1998.

HEYTHUM, Antonin. Industrial Design in Wartime. Architect and Engineer (September 1940): 24; and Architect and Engineer (October 1942).

HEYTHUM, Antonin. Industrial Design Section of the California Institute of Technology. Report of Activities, 1941-42, Minireview of California Institute of Technology (June 1942): 4-10; Bulletin of the California Institute of Technology 54: 4: 211. Available online at: http://calteches.library. caltech.edu/82/2/ES5.4.1942.pdf. 
JAGENDORF, M. 1940. The Night in New York. Sentinel (December 28, 1940).

MUNDY, Jennifer (ed.). 2016. Man Ray: Writings on Art. Tate Publishing, 2016.

New York City Theatre Arts Monthly (February 1941); unidentified clipping; Archive of the New School.

New School (New York, N.Y.). Curriculum The New School for Social Research 1941 Spring. circa 1940. New School course catalogs; Public Engagement course catalogs; General course catalogs. New School Archives and Special Collections Digital Archive [online]. [accessed on 23 Mar 2017]. Available online at: http://digitalarchives.library.newschool.edu/index.php/Detail/ objects/NS050101_ns1941sp.

PISCATOR, Erwin. 1940. Piscator Gives Aims Of 'Studio Theatre' Project to Be Test Ground for New and Old Work. New York Times (Sunday, November 17, 1940).

PULOS, Arthur J. 1990. The American Design Adventure, 1940-1975. Cambridge, MA.: MIT Press, 1990: 169.

Radio Retailing Today (January 1944): 102. Available at: http://www.americanradiohistory.com/ Archive-Radio-Retailing/40s/Radio-Retailing-1944-01.pdf

ŠTĚDROŇ, Miloš. 1998. Leoš Janáček a hudba 20 století. Paralely, sondy, dokumenty. Brno: Nadace Universitas Masarykiana, 1998: 123-124.

Thompson Library, Special Collections, Collection of Jarka Burian, Heythum 84060 31; the felt pen margin reads: "Heythum, Lear".

TEIGE, Karel. 1927-28. K teorii konstruktivismu. Stavba 6 (1927-28): 7-24.

The Play, Piscator Stages a Production of King Lear with Sam Jaffe in the Title Part. New York Times (December 16, 1940).

WATTS, Richard Jr. 1940. The Theaters. New York Herald Tribune (December 16, 1940).

\section{doc. Vlasta Koubská}

Department of Scenography,

Theatre Academy of Performing Arts (DAMU), Prague, Czech Republic

vlasta.koubska@damu.cz

Vlasta Koubská is assistant professor of history and theory of stage design at the Department of Scenography, Theatre Academy of Performing Arts (DAMU) in Prague. For many years she has been curator and head of the Theatre Department of the National Museum in Prague responsible for the collections of stage designs and costumes. Based on her knowledge of the collections, she has curated numerous exhibitions and written books and essays dealing predominantly with Czech Avant-garde scenography of the 1920s and 1930s (F. Tröster, F. Zelenka, J. Čapek, B. Feuerstein, F. Muzika, V. Hofman, A. V. Hrska, F. Tichý, J. Malina, O. Schindler, J. Zbořilová and others). 